\title{
Development of Proving Ground Field Test for Establishment of Vehicle Accelerated Corrosion Test Procedure in Malaysia
}

\author{
L. Anuar ${ }^{1,2}$, A. Amrin ${ }^{1 *}$, R. Mohamad ${ }^{1}$, S. A. Aziz ${ }^{1}$ and M. Toozandehjani ${ }^{1}$ \\ ${ }^{1}$ Razak Faculty of Technology and Informatics, UTM Kuala Lumpur, Jalan Sultan \\ Yahya Petra, 54100, Kuala Lumpur, Malaysia \\ *Email: astuty@utm.my \\ Phone: +60123858682, +603-21805178 \\ ${ }^{2}$ Perusahaan Otomobil Nasional Berhad, Persiaran Kuala Selangor, Seksyen 26, \\ 40400, Shah Alam, Selangor, Malaysia
}

\begin{abstract}
This paper presents the field tests conducted as part of activity to establish the vehicle accelerated corrosion test procedure in Malaysia, initiated by the national car manufacturer company, PROTON, Malaysia. Vehicle accelerated corrosion test is a combination of corrosion exposures and durability cycles to accelerate the corrosion process and detect potential failures that may occur during in-service conditions. PROTON conducts the vehicle accelerated corrosion test at external test centres in overseas. However, due to the different climatic of test location, some of the corrosion problems were found to be varied and many did not address the actual corrosion problems detected in Malaysia markets. Hence, the primary aim of this study is to establish a suitable corrosion driving procedure to accommodate the hot and humid environment using facilities in PROTON Test Track. Three corrosion driving procedures were designed based on the number of corrosion exposures and designated as Field Tests 1, 2 and 3. Analysis ruled out that Field Test 3 provides moderate corrosion rate of 0.077$0.842 \mathrm{~mm} /$ year and potentially to be the best suited for accelerated corrosion test procedure in Malaysia due to its close replication of actual cosmetic corrosion behaviour observed in Malaysia.
\end{abstract}

Keywords: Vehicle accelerated corrosion test; field test; mud trough; salt trough; gravel road; cosmetic corrosion rating (CCR)

\section{INTRODUCTION}

Corrosion is defined as the destruction or deterioration of a material due to reactions with its environment [1,2]. It is also explained as physicochemical interaction between metal and its environment that results in changes of properties which may lead to significant impairment of function and system [3]. Vehicles are regularly exposed to dynamic and environment exposures during its service. This condition has contributed many corrosion damages on metal body panels and components such as pitting corrosion, crevice corrosion, metal loss and perforation [4]. These corrosion damages do not only affect the external appearance of a vehicle but also affects the overall vehicle performance, integration and safety $[5,6]$.

PROTON as a car manufacturer, is responsible to design and engineer a vehicle with low risk of corrosion damages and provide good protection against corrosion. In the vehicle development programme, corrosion is one of the important tests to ensure the 
performance and durability of vehicle in response to climatic and environmental exposures. Vehicle accelerated corrosion test is a combination of corrosion exposures and durability cycles to accelerate the corrosion process and detect potential failures that may occur during in-service conditions. The tests have been conducted at external test centres in overseas. PROTON has adopted the proving ground accelerated corrosion test similar to other global car manufacturers. The test simulates the effects of one year accelerated corrosion that mimics the severe corrosive environment of north-east and south east of America [7]. However, after series of tests conducted, the test results obtained were varies and do not correlate with the actual corrosion conditions observed in the Malaysia market. The difference in results obtained may be due to different corrosion acceleration targeted and materials used for continental climate compared with the tropical climatic countries. Consequently, the national car manufacturer decides to design its own test procedure that accommodates the environment of the targeted market especially for Malaysia and tropical climate countries.

This research outlines the study conducted in collaboration with the national car company named Perusahaan Otomobil Nasional Berhad (PROTON) to establish a suitable corrosion driving procedure to accommodate the hot and humid environment using facilities in PROTON Test Track. Three different Field Test were carried out and designated as Field Tests 1, 2 and 3. The Field Tests were based on the number of corrosion exposures wherein Field 1 was designed to provide a high repetition of salt trough, mud trough and gravel road while Test 2 and 3 were designed to provide a reduced number of corrosion exposures than Field Test 1. Cosmetic corrosion rating (CCR) evaluation was the main determinant factor in selecting the potential test procedure and supported with weight loss analysis of test coupons from each field test.

\section{METHODS AND MATERIALS}

Figure 1 shows the flowchart of field tests done in this research. The PROTON Test Track was used as the test ground (Figure 2). The newly constructed corrosion test facilities of mud trough, salt trough and gravel road were utilized as shown in Figure 2. Other durability test facilities in PROTON Test Track such as gradient slope, simulation track and semi high speed circuit were also used to provide durability inputs to test vehicles [8]. Vehicle and test coupon preparation were conducted prior to field test. Various iteration of field tests conducted and Field Test 1,2 and 3 are presented in this study.

Test vehicles were underwent cosmetic corrosion rating (CCR) assessment to identify any defects or abnormalities on all areas prior to test. Cosmetic corrosion is described as aesthetically displeasing defects such as blisters, chipping, scratches, peeloff and rusty [9]. The CCR assessment utilized the cosmetic corrosion rating scale in Table 1, benchmarked from Millbrook Proving Ground's and MIRA Proving Ground's test procedure $[7,10]$. The results from field tests were also analysed in terms of weight loss. 


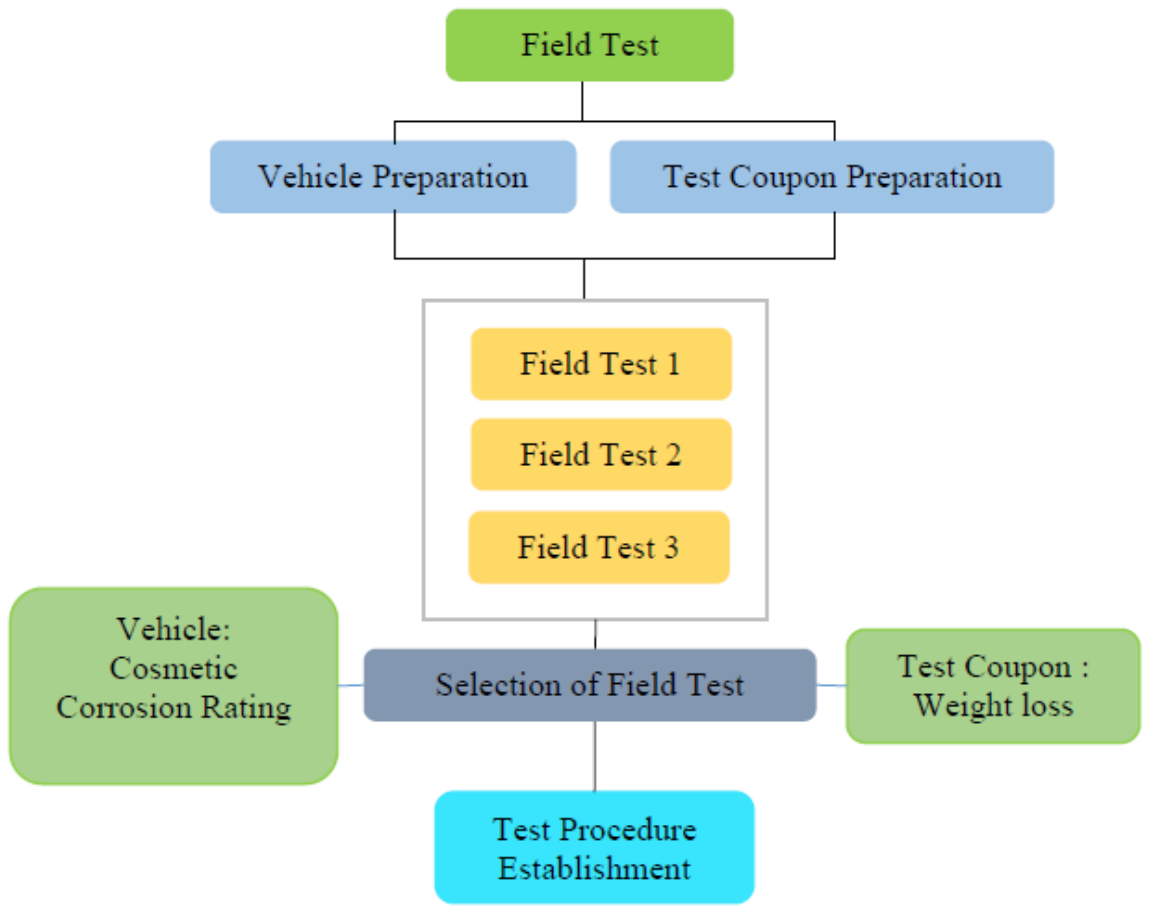

Figure 1. Flowchart of field test.
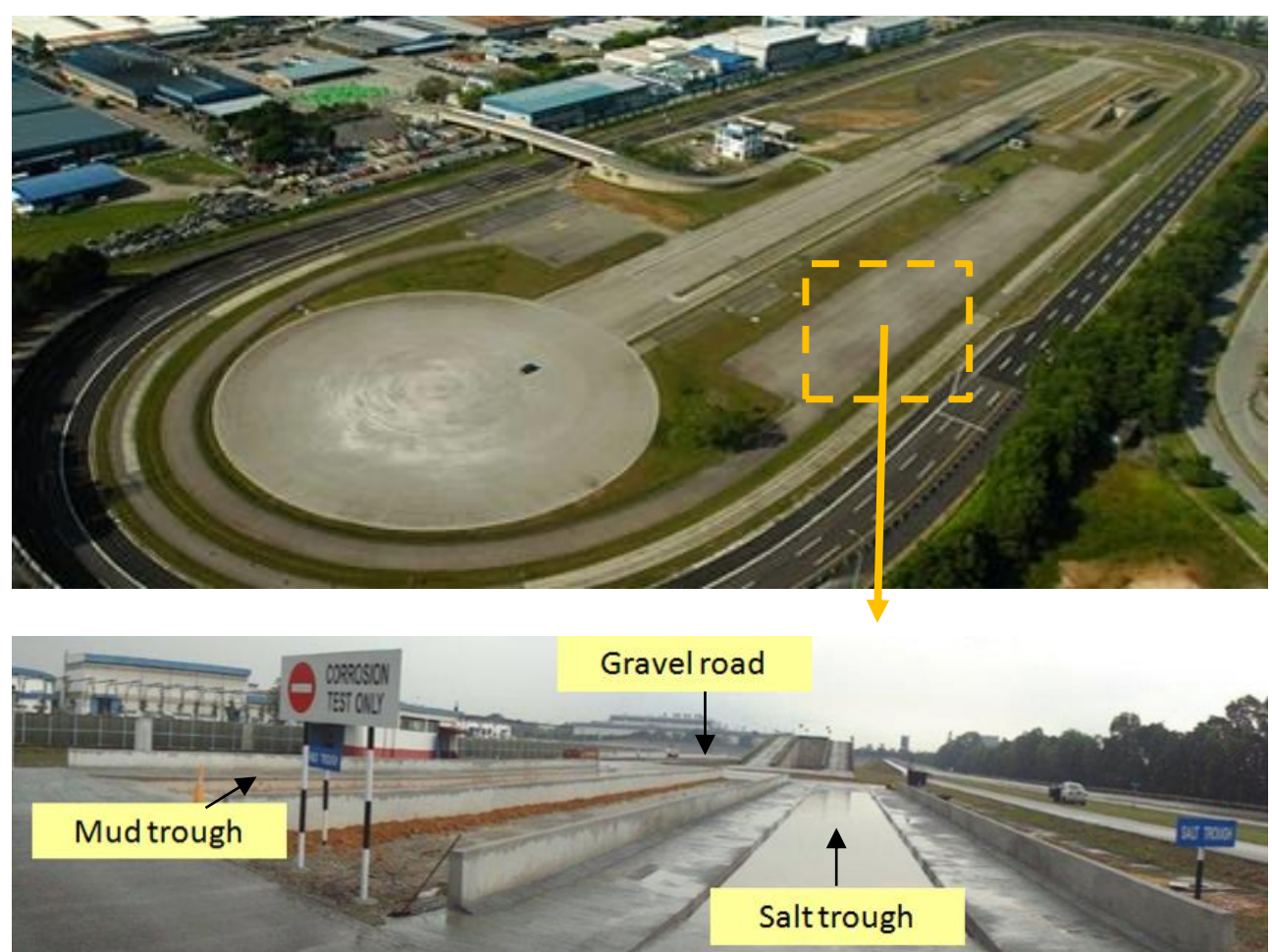

Figure 2. PROTON Test Track and Corrosion test facilities.

CCR Assessment was conducted to observe the CCR of vehicle and its components upon completion of each simulated corrosion year, as per Table 1. The CCR evaluation were divided into four areas that are underbody, underhood, exterior and 
secondary surfaces and interior surfaces with a specific requirement for test compliance as listed in Table 2 [7]. In the tabulated results, compliances with requirements were shaded in green colour for compliance and in orange colour for non-compliances.

Table 1. Cosmetic corrosion rating (CCR) scale.

\begin{tabular}{cc}
\hline Scale & Rating \\
\hline 10 & No visible corrosion \\
9 & Trace of corrosion \\
8 & Slight corrosion \\
7 & Light corrosion \\
6 & Moderate corrosion \\
5 & Medium corrosion \\
4 & Mostly corroded \\
3 & Totally corroded \\
2 & Severe corrosion \\
1 & Perforation \\
\hline
\end{tabular}

Table 2. Cosmetic concern areas and requirement.

\begin{tabular}{lcc}
\hline Cosmetic concern area & $\begin{array}{c}\text { Compliance at } \\
\text { Corrosion Year }\end{array}$ & $\begin{array}{c}\text { Requirement } \\
\text { Cosmetic Corrosion Rating } \\
\text { (CCR) }\end{array}$ \\
\hline Underbody & 1 & 6 and above \\
Underhood & 2 & 6 and above \\
Exterior and secondary surfaces & 6 & 6 and above \\
Interior surfaces & 10 & 7 and above \\
\hline
\end{tabular}

There were three corrosion driving cycles designed to compare the corrosion effects to vehicles when different routines of driving cycles were provided. Figure 3 shows the corrosion driving cycles for Field Test 1,2 and 3. The cycles have been agreed by technical committee of PROTON. Test vehicles were driven to complete mileage of $140 \mathrm{~km}$ per day. The cycles continue to complete $1,400 \mathrm{~km}$ as representation of one corrosion year. Simulation were continued until completion of 14,000 km for simulation of accelerated ten corrosion years as benchmarked from previous test experiences at Millbrook Proving Ground, UK [7].

Test coupons were used to measure corrosion exposure during the field tests. Weight loss technique was applied in accordance to ASTM G4:2001- Standard Guide for Conduction Corrosion Coupon Test in Field Application [11]. Test coupons shown in Figure 4 were fabricated by cutting from Steel Plate Cold-rolled Commercial (SPCC) grade steel coil into coupons with dimensions of $50 \times 25 \times 1.5 \mathrm{~mm}$. The coupons were installed at under floor of test vehicle as recommended in SAE J 1293:1990 [12] to measure the corrosion rate using weight loss technique (Figure 3). 

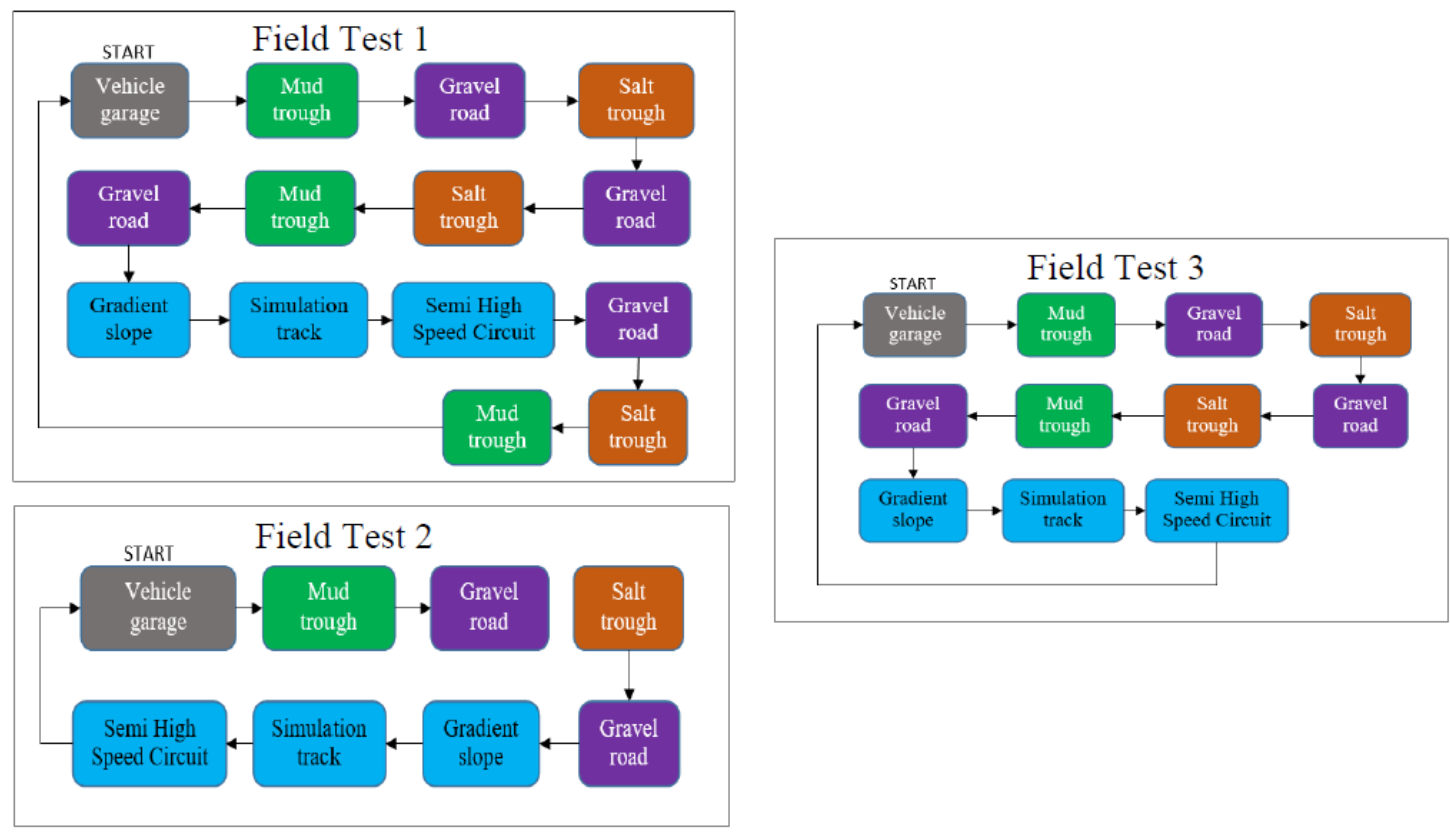

Figure 3. Corrosion driving cycles for field tests.

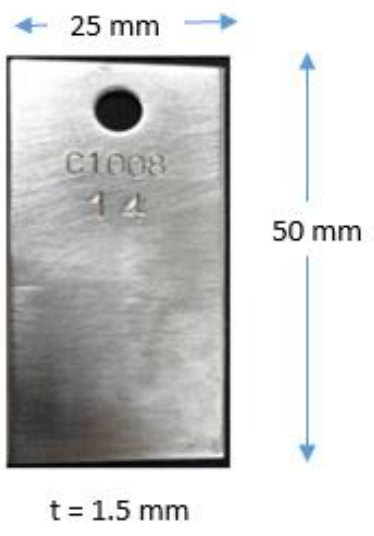

(a)

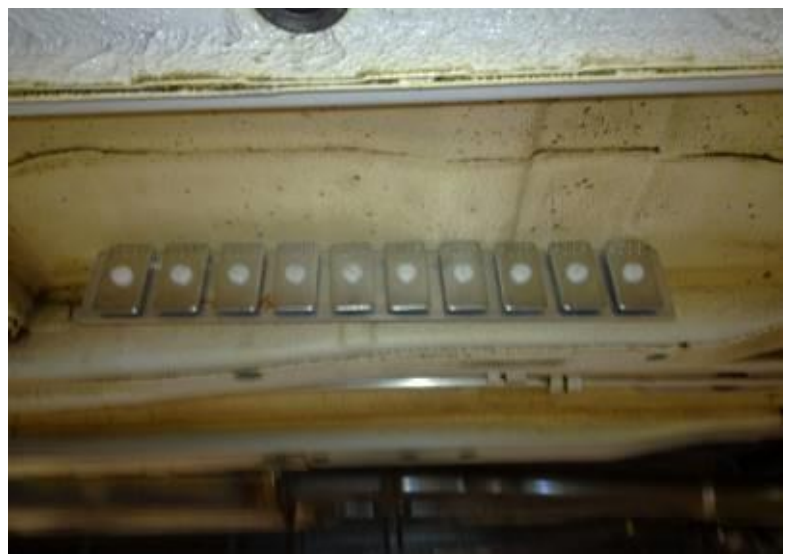

(b)

Figure 4. (a) Test coupons for corrosion rate measurements and (b) test coupons installed at under floor of test vehicles.

The weight loss obtained was calculated in accordance with ASTM G1-03 for corrosion rate measurement of each corrosion years using Eq. (1) [13]:

$$
\text { Corrosion Rate }=(K \times W) /(A \times T \times D)
$$

where $K=$ constant, $8.76 \times 10^{4}$ (mm/year), $T=$ time of exposure in hours, $A=$ area in $\mathrm{cm}^{2}, W=$ mass loss in grams, and $D=$ density in $\mathrm{g} / \mathrm{cm}^{3}$.

The cleaning procedure also followed the same standard. In this research both mechanical and chemical method were used depending on the severity of severity of corrosion. The mechanical procedure was brushing and ultrasonic cleaning. 


\section{RESULTS AND DISCUSSION}

The cosmetic corrosion rating (CCR) and corrosion rate measurement were analysed and discussed in this section in order to select the potential corrosion driving cycles. The Field Test 1 underwent 3 times of salt trough, mud trough and gravel roads exposures in each driving cycle. The CCR for Field Test 1 is presented in Table 3. It can be seen that the area of underbody, underhood and exterior surfaces complied with test requirements outlined in Table 2. Further exposures during Test 1 revealed that the underbody has started to experience CCR 1 (perforation) at Year 7.

Table 3. Cosmetic corrosion rating (CCR) for field test 1.

\begin{tabular}{|c|c|c|c|c|c|c|c|c|c|c|c|}
\hline \multirow[t]{2}{*}{ Area } & \multicolumn{10}{|c|}{ CCR at accelerated corrosion years } & \multirow[t]{2}{*}{ Issues } \\
\hline & 1 & 2 & 3 & 4 & 5 & 6 & 7 & 8 & 9 & 10 & \\
\hline Underbody & 9 & 7 & 7 & 7 & 6 & 5 & 1 & 1 & 1 & 1 & $\begin{array}{c}\text { Exhaust } \\
\text { flange }\end{array}$ \\
\hline Underhood & 9 & 7 & 7 & 6 & 5 & 5 & 5 & 4 & 3 & 2 & Fasteners \\
\hline $\begin{array}{l}\text { Exterior and } \\
\text { secondary } \\
\text { surfaces }\end{array}$ & 10 & 10 & 10 & 9 & 9 & 8 & 8 & 8 & 7 & 6 & $\begin{array}{c}\text { Not } \\
\text { available }\end{array}$ \\
\hline $\begin{array}{l}\text { Interior } \\
\text { surfaces }\end{array}$ & 10 & 10 & 8 & 8 & 8 & 7 & 7 & 7 & 7 & 6 & $\begin{array}{l}\text { Seat } \\
\text { frame }\end{array}$ \\
\hline
\end{tabular}

The exhaust flange was unexpectedly experienced a component failure where a weld detachment occurred as shown in Figure 5(a). The weld detachment failure was considered as loss of function and failed to meet vehicle and component functional use. While, for interior surfaces, at year 10, the seat frame experienced moderate corrosion (CCR 6) as shown in Figure 5(b). Figure 6 shows example of exterior/secondary surfaces that were evaluated during the test. The exterior/secondary surfaces were observed to comply with the requirement of minimum rating 6 . However, some abvious corrosion areas was found like bleed of rust on fuel filler lid as shown in Figure 6(c).
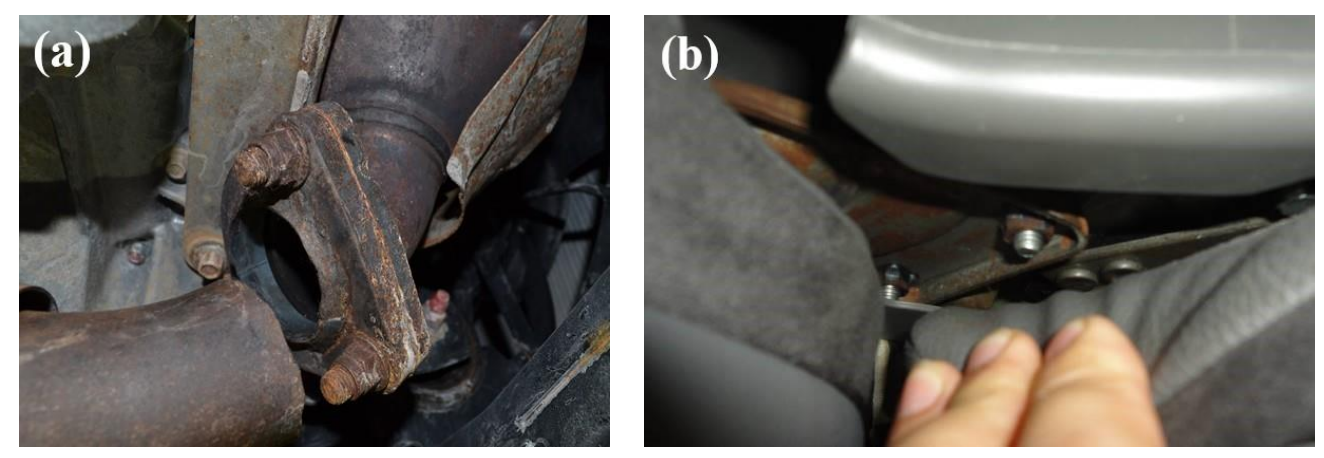

Figure 5. (a) Exhaust flange failure and; (b) rusty seat frame.

The overall observation of field test 1 showed a severe cosmetic corrosion condition and deterioration of components. It mimics the previous test results conducted by PROTON at external test centres. This corrosion driving cycles are assumed to be able to accelerate the corrosion behaviour, however the failure may not be relevant to actual Malaysia market and its component durability performance. 

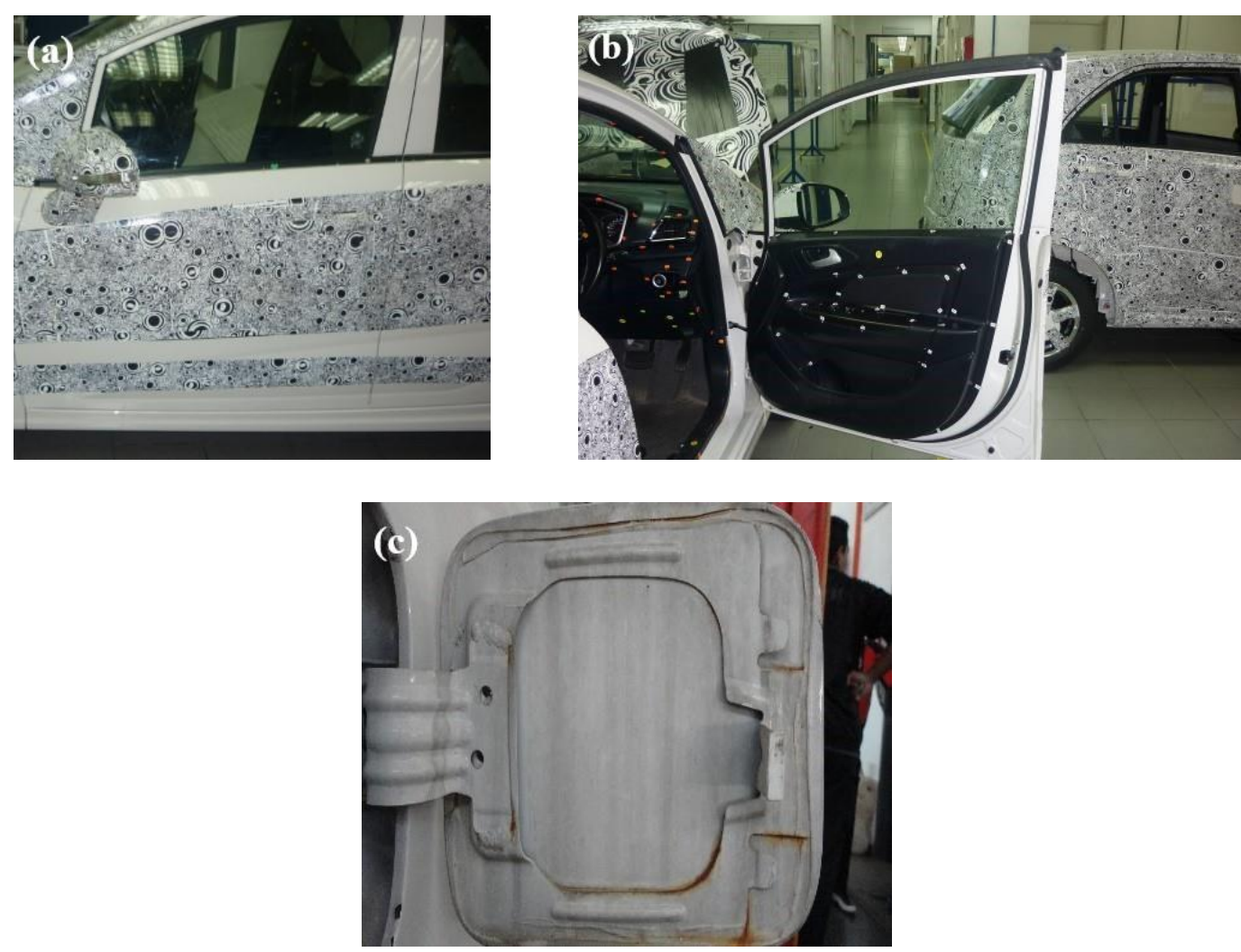

Figure 6. (a) exterior of vehicle, (b) secondary surfaces at door panel and; (c) bleed of rust at fuel filler lid.

The findings from field test 1 has led to commence with field test 2 that provide a reduce repetition to 1 time of salt trough, mud trough and gravel roads in each driving cycle. Table 4 shows the area of underbody, underhood and exterior surfaces have complied with the test requirements while interior surface maintained the same CCR rating as per field test 1 due to the same specification of material and coating of the part.

Table 4. Cosmetic corrosion rating (CCR) for field test 2.

\begin{tabular}{|c|c|c|c|c|c|c|c|c|c|c|c|}
\hline \multirow[t]{2}{*}{ Area } & \multicolumn{10}{|c|}{ CCR at accelerated corrosion years } & \multirow[t]{2}{*}{ Issues } \\
\hline & 1 & 2 & 3 & 4 & 5 & 6 & 7 & 8 & 9 & 10 & \\
\hline Underbody & 9 & 9 & 8 & 8 & 8 & 7 & 7 & 6 & 5 & 5 & $\begin{array}{c}\text { Not } \\
\text { available }\end{array}$ \\
\hline Underhood & 9 & 9 & 8 & 8 & 7 & 7 & 6 & 5 & 5 & 4 & $\begin{array}{c}\text { Not } \\
\text { available }\end{array}$ \\
\hline $\begin{array}{l}\text { Exterior and } \\
\text { secondary } \\
\text { surfaces }\end{array}$ & 10 & 10 & 10 & 9 & 9 & 9 & 9 & 8 & 8 & 8 & $\begin{array}{c}\text { Not } \\
\text { available }\end{array}$ \\
\hline $\begin{array}{l}\text { Interior } \\
\text { surfaces }\end{array}$ & 10 & 10 & 9 & 9 & 8 & 7 & 7 & 7 & 7 & 6 & Seat frame \\
\hline
\end{tabular}

The overall CCR for field test 2 revealed a better CCR results compared with field test 1 until the end of accelerated corrosion years. There were also no severe corrosion problems to the coating and components. This showed that the reduction of salt trough, mud trough and gravel roads exposures provided a less corrosion effect and displayed a better CCR than field test 1. 
The findings from field test 1 and 2 has led to field test 3 where test cycle was modified to two times of salt trough, mud trough and gravel road in each driving cycles. The CCR results were tabulated in Table 5. The CCR result for field test 3 showed compliances at all areas at each target year. No perforation and component malfunction problems were detected throughout the test. This showed that the driving cycles of Field Test 3 were moderate and do not damage the components excessively. The vehicle and components condition after Field Test 3 were seen to be comparable with data from actual vehicle in service condition collaborated and agreed with PROTON EDAR. Hence, driving cycles of field test 3 has the potential to mimic the corrosion condition of Malaysia market.

Furthermore, corrosion rate measurements were conducted using weight loss technique of the test coupons. The corrosion rates of field test 1 , field test 2 and field test 3 were $0.057-1.244,0.040-0.324$ and $0.077-0.842 \mathrm{~mm} /$ year, respectively. The corrosion rates of field test 1, 2 and 3 were overlayed in Figure 7 . The field test 1 was found having the higher corrosion rate exposure compared to field test 2 and 3. This was due to high repetition of corrosion exposures of mud trough, salt trough and gravel road. Corrosion rates of field test 2 were found to be the lowest compared to field test 1 and 3 . This was due to the lesser corrosion exposures given to the test vehicles while field test 3 was found experiencing a moderate corrosion exposures.

Table 5. Cosmetic corrosion rating (CCR) for field test 3.

\begin{tabular}{|c|c|c|c|c|c|c|c|c|c|c|c|}
\hline \multirow[t]{2}{*}{ Area } & \multicolumn{10}{|c|}{ CCR at accelerated corrosion years } & \multirow[t]{2}{*}{ Issues } \\
\hline & 1 & 2 & 3 & 4 & 5 & 6 & 7 & 8 & 9 & 10 & \\
\hline Underbody & 9 & 9 & 9 & 8 & 8 & 7 & 7 & 7 & 6 & 6 & $\begin{array}{c}\text { Not } \\
\text { available }\end{array}$ \\
\hline Underhood & 9 & 9 & 9 & 8 & 8 & 7 & 7 & 7 & 6 & 6 & $\begin{array}{c}\text { Not } \\
\text { available }\end{array}$ \\
\hline $\begin{array}{l}\text { Exterior and } \\
\text { secondary } \\
\text { surfaces }\end{array}$ & 10 & 10 & 10 & 10 & 10 & 10 & 9 & 9 & 9 & 9 & $\begin{array}{c}\text { Not } \\
\text { available }\end{array}$ \\
\hline $\begin{array}{l}\text { Interior } \\
\text { surfaces }\end{array}$ & 10 & 10 & 9 & 9 & 8 & 8 & 7 & 7 & 7 & 7 & $\begin{array}{c}\text { Not } \\
\text { available }\end{array}$ \\
\hline
\end{tabular}

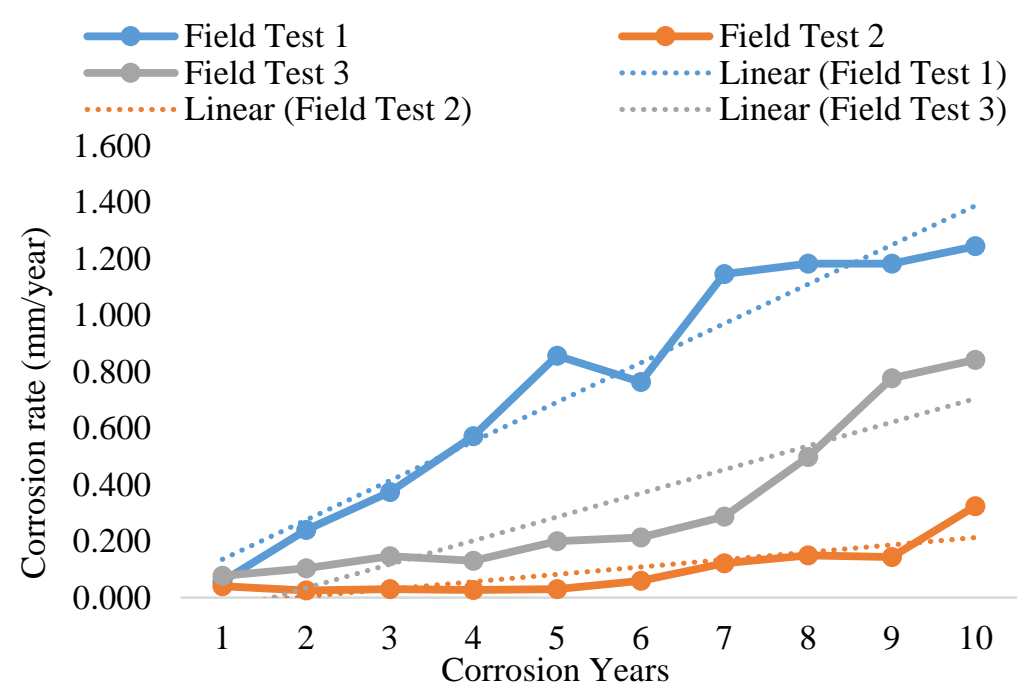

Figure 7. Corrosion rate measurements of different field tests. 


\section{CONCLUSION}

Three different ground field tests were conducted to establish a suitable corrosion driving procedure that accommodate the hot and humid environment in Malaysia market. Based on the designated field tests, corrosion driving cycles designated for field test 1 were found to be severe and deteriorating to the test vehicle since the highest corrosion rate of 0.057-1.244 mm/year was obtained. In addition, components breakdown and perforation were observed indicating that field test 1 may not be suitable to be selected as the vehicle accelerated corrosion test procedure. The field test 3 was seen to be the most potential corrosion driving cycles in establishing a vehicle accelerated corrosion test procedure for Malaysia market. This is due to its moderate corrosion exposures and ability to provide the cosmetic corrosion condition similar to the actual corrosion condition experienced in Malaysia tropical climate along with a moderate coorosion rate $(0.077-0.842 \mathrm{~mm} /$ year $)$. However, further vehicle benchmarking and validation activities have been planned for more data collection to support and select field test 3 as the vehicle accelerated corrosion test procedure in Malaysia.

\section{ACKNOWLEDGEMENT}

The authors would like to thank to Universiti Teknologi Malaysia for research grant (GUP: PY/2017/001670) and PROTON for technical information and supervision.

\section{REFERENCES}

[1] Fontana MG. Corrosion Engineering. $3^{\text {rd }}$ ed. $12^{\text {th }}$ reprint. New Delhi: Tata McGraw-Hill; 2005.

[2] Cicek V, Al-Numan B. Corrosion Engineering and Cathodic Protection Handbook. United States of America: John Wiley \& Sons Inc; 2017.

[3] International Organization for Standardization. ISO 8044 Corrosion of metals and alloys -- Basic terms and definitions. Swirtzerland: ISO International; 2015.

[4] Hook G. History: A treatise on the development of a proving ground corrosion test. Society of Automotive Engineers 1997; 770294.

[5] Oh S, Min B. Development of Accelerated Corrosion test Mode Considering Environmental Condition. SAE 2002 World Congress \& Exhibition: Society of Automotive Engineer International; p. 2002-01-1231.

[6] Hilti.Corrosion Handbook. Liechtenstein: Hilti Corp., Schaan, 2015.

[7] Millbrook Proving Ground (2012). Millbrook Tracks [Brochure]. London: Millbrook Proving Ground.

[8] Testing \& Development department, PROTON. Test Track Manual. Rev 0, 2014.

[9] Society of Automotive Engineers. SAE J 1617. Body Corrosion-A Comprehensive Introduction. United State of America: SAE International; 2016.

[10] MIRA Proving Ground. Vehicle Corrosion Test [Brochure]. Nuneton: MIRA Proving Ground; 2012.

[11] ASTM G4-95. Standard guide for conducting corrosion coupon tests in field applications, United State of America: ASTM International; 1995.

[12] Society of Automotive Engineers. SAE J1293. Undervehicle coupon corrosion tests. United State of America: SAE International; 1990.

[13] ASTM G1-03. Standard Practice for preparing, cleaning, and evaluating corrosion test specimens, United State of America: ASTM International; 2017. 